\title{
Pembelajaran Literasi Finansial Untuk Tingkat Dasar
}

\author{
Financial Literacy Learning for Primary Education
}

\author{
Adib Rifqi Setiawan \\ $\Lambda$ lobatnio Research Society $(\Lambda \mathrm{RS})$ \\ basiceduresearch@gmail.com
}

\begin{abstract}
Abstrak
Riset ini merancang desain pembelajaran untuk membimbing murid tingkat dasar dalam mencapai literasi keuangan. Pendekatan yang digunakan adalah model eksplorasi sekuensial metode campuran. Hasil ini menunjukkan bahwa keabsahan dan keandalan desain ini secara umum pada kategori dapat digunakan.
\end{abstract}

Kata-kata Kunci: desain pembelajaran; literasi finansial; pendidikan dasar; sekolah dasar;

\begin{abstract}
This research constructs learning design to guide primary students on achieving financial literacy. The approach used is mixed method sequential exploratory model. This results shows that validity and reliability of this design in general on the category can be used.
\end{abstract}

Keywords: elementary education; financial literacy; learning design; primary school;

\section{A) Pendahuluan}

Masalah pendidikan finansial mulai diperhatikan serius sejak 2005 silam oleh OECD (Organisation for Economic Co-operation and Development) selaku organisasi multilateral yang berupaya meningkatkan kualitas manusia secara global (OECD, 2005, hal. 5). Secara khusus OECD menyarankan bahwa pendidikan finansial harus sedini mungkin dimulai di sekolah yang merupakan tahap awal kehidupan murid. Alasan utama yang mendasari saran tersebut ialah nilai penting berfokus kepada generasi muda untuk membekali keterampilan yang penting sebelum terlibat aktif dalam transaksi finansial serta relatif lebih efisien untuk melakukan pendidikan finansial di sekolah ketimbang melakukan tindakan perbaikan untuk orang yang berusia tua. Saran OECD pada 2005 tersebut kemudian dipertimbangkan sebagai bahan mengembangkan kerangka kerja literasi dari PISA (Programme for International Students Assessment) (OECD, 2019, hal. 119).

PISA adalah program internasional OECD untuk menilai performa akademik murid berusia 15 tahun yang bertujuan untuk memberi bahan dalam meningkatkan pendidikan negara yang terlibat (OECD, 2019, hal. 11). Penilaian PISA berfokus terhadap kemampuan murid untuk menggunakan pengalaman terlibat pembelajaran ke dalam keseharian (OECD, 2019, hal. 128). Fokus ini membedakan penilaian PISA dengan TIMSS (Trends in International Mathematics and Science Study), program dari IEA (International Association for the Evaluation of Educational Achievement), yang fokus terhadap penguasaan konten kurikuler tertentu. Nasichatul Ummah (2018) mengungkap bahwa membiasakan murid untuk menggunakan pengalaman terlibat pembelajaran ke dalam keseharian lebih penting ketimbang penguasaan konten kurikuler tertentu. Fokus PISA dan ungkapan Nasichatul Ummah (2018) tersebut selaras dengan penafsiran 'Abd al-Roḥmān ibn Abī Bakr alSuyūṭ̄ terhadap ayat 122 al-Taubat yang disajikan dalam Tafsīr al-Jalālayn-yang ditulis untuk melanjutkan kerja Muḥammad ibn Aḥmad al-Maḥallī (al-Maḥallī \& al-Suyūṭ̂̄, 2010, hal. 263). 
Penilaian PISA biasanya dikenal lebih luas dengan istilah literasi. Literasi dalam kerangka kerja PISA dikelompokkan menjadi empat bagian: membaca, matematis, saintifik, dan finansial (OECD, 2019, hal. 11-2). Ketiga kelompok literasi pertama, yakni membaca, matematis, dan saintifik, masing-masing sudah pernah menjadi fokus utama penilaian pada tahun tertentu, yang diperbarui setiap 9 tahun. Sementara kelompok terakhir yakni literasi finansial, baru masuk dalam penilaian sejak 2012 tanpa pernah menjadi fokus utama, malah sampai sekarang masih menjadi penilaian pilihan.

Fakta tersebut membuat literasi finansial lebih sedikit diperhatikan di Indonesia, baik dari sisi kajian akademik maupun praktik pembelajaran, khususnya untuk pendidikan dasar. Namun, perhatian sedikit tidak membuat government Indonesia luput memberi perhatian. Bentuk perhatian tersebut ialah menetapkan kebijakan untuk meningkatkan literasi finansial melalui program Strategi Nasional Literasi Finansial pada 19 November (OJK, 2017; OECD, 2015, hal. 12; Kementerian Sekretariat Negara RI, 2013). Program ini dirilis sebagai upaya mewujudkan literasi finansial masyarakat Indonesia, sehingga dapat memanfaatkan produk dan layanan jasa finansial yang sesuai untuk mencapai kesejahteraan berkelanjutan.

Berdasarkan sebaran informasi yang disampaikan, kami memandang bahwa literasi finansial perlu diterapkan ke dalam program pembelajaran untuk tingkat dasar. Program tersebut dapat diwujudkan dengan cara mengkaji indikator yang dibekalkan kepada murid, bukan sekadar membiasakan murid mengerjakan soal literasi finansial. Karena itu, riset ini diarahkan untuk menyusun program pembelajaran guna mewujudkan pendidikan literasi finansial untuk tingkat dasar. Secara khusus, kami bermaksud menyusun program yang dapat digunakan dalam pembelajaran di madrasah ibtidaiyah (MI) yang kami kelola tanpa perlu mengubah struktur kurikulum yang telah berlaku sejak lama. Sehingga sasaran murid yang dipilih dalam riset ini ialah di tingkat pendidikan dasar.

Pilihan mengarahkan kepada murid di tingkat pendidikan dasar didasari fakta bahwa pada rentang tersebut sebagian besar murid dapat dikatakan mandiri ketika terlibat transaksi finansial, meski masih bergantung kepada wali sendiri dalam memperoleh pemasukan. Pertimbangan lain yang mendasari tujuan kami ialah nilai penting berfokus kepada anak-anak untuk membekali keterampilan yang penting untuk keseharian serta lebih efektif dalam melatih literasi finansial di tingkat dasar yang kerumitan topik pembelajaran lebih sederhana dibanding tingkat menengah dan tinggi. Karena itu, pertanyaan yang menjadi fokus riset ini ialah, "Bagaimana desain pembelajaran untuk membimbing murid tingkat dasar dalam memperoleh literasi finansial?"

\section{B) Metode}

Data yang dibutuhkan dalam penelitian ini berupa kajian pustaka tentang karakteristik dan kerangka kerja literasi finansial serta survei terhadap rancangan dan temuan dari uji coba program yang disusun. Berdasarkan tujuan penelitian dan kebutuhan data, dapat dipakai pendekatan R\&D (research and development) desain model 4D berupa define, design, develop, dan disseminate (Thiagarajan, Semmel, \& Semmel, 1974, hal. 5).

Desain model 4D dipilih karena kami perlu beberapa tahap yang masing-masing memerlukan cara pengumpulan dan pengolahan data yang tidak selalu sama. Namun, karena keterbatasan tenaga, desain model 4D dikurangi menjadi 3 tahap berupa define, design, dan develop. 
Tahap define dilakukan untuk mengkaji pustaka terkait kerangka kerja literasi finansial. Luaran kajian tersebut dijadikan sebagai acuan dalam menyusun instrumen penilaian pembelajaran dan lembar kerja murid (LKM) di tahap design. Susunan yang diperoleh dipakai sebagai bahan merancang program pembelajaran dalam bentuk silabus di tahap develop. Tahap develop juga dipakai untuk menganalisis keabsahan dan keandalan perangkat pembelajaran melalui ujicoba terbatas.

Tabel 1. Desain Riset

\begin{tabular}{|c|c|c|c|c|}
\hline Tahap & $\begin{array}{c}\text { Pengumpulan } \\
\text { Data }\end{array}$ & $\begin{array}{l}\text { Pengolahan } \\
\text { Data }\end{array}$ & Partisipan Riset & Instrumen Riset \\
\hline Define & Kajian Pustaka & $\begin{array}{c}\text { Analisis } \\
\text { Deskriptif }\end{array}$ & Penulis & - \\
\hline Design & Matriks Analisis & $\begin{array}{c}\text { Analisis } \\
\text { Deskriptif }\end{array}$ & Penulis & - \\
\hline \multirow{2}{*}{ Develop } & Judgement Expert & $\begin{array}{l}\text { Penyekoran } \\
\text { Hasil }\end{array}$ & $\begin{array}{l}\text { Akademisi finansial, } \\
\text { pembelajaran, dan } \\
\text { pendidikan dasar serta } \\
\text { praktisi finansial dan } \\
\text { bahasa. }\end{array}$ & Lembar Survei Validasi \\
\hline & $\begin{array}{c}\text { Internal } \\
\text { Consistency }\end{array}$ & $\begin{array}{l}\text { Perhitungan } \\
\text { Koefisien Alfa }\end{array}$ & $\begin{array}{l}\text { Murid tingkat pendidikan } \\
\text { dasar sebanyak } 102 \text { orang }\end{array}$ & $\begin{array}{c}\text { Lembar Pengamatan } \\
\text { Pelaksanaan Rencana } \\
\text { Pembelajaran, Lembar } \\
\text { Kerja Murid, dan Instrumen } \\
\text { Penilaian }\end{array}$ \\
\hline
\end{tabular}

\section{C) Hasil dan Pembahasan}

\section{1) Tahap Define}

Literasi finansial dalam kerangka kerja PISA dibagi ke dalam 3 domain: konten, proses, dan konteks (OECD, 2019, hal. 119-164). Domain konten adalah bidang yang harus dimengerti ketika terlibat transaksi finansial. Domain konten mencakup: uang dan transaksi, perencanaan dan pengelolaan finansial, risiko dan imbalan, serta lanskap finansial. Domain proses adalah sisi kognitif yang digunakan untuk menggambarkan kemampuan dalam mengenali dan menerapkan konsep terkait transaksi serta dalam memahami, menganalisis, mempertimbangkan, mengevaluasi dan menyarankan solusi finansial. Domain proses mencakup: mengidentifikasi informasi finansial, menganalisis informasi dalam konteks finansial, mengevaluasi masalah finansial, serta menerapkan pengetahuan dan pemahaman finansial. Sementara domain konteks mengacu kepada situasi terkait penerapan pengetahuan, keterampilan, dan pemahaman finansial. Domain konteks mencakup pendidikan dan pekerjaan, rumah dan keluarga, individu, serta masyarakat. 


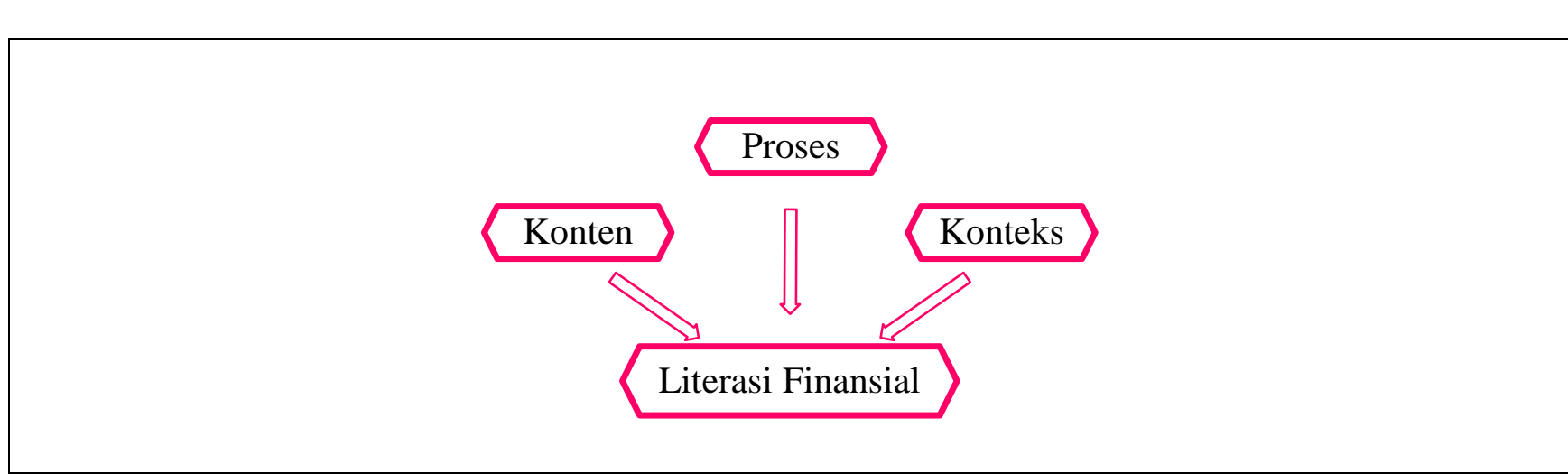

\section{Gambar 1. Kaitan antar Domain Literasi Finansial}

Konten uang dan transaksi mencakup kesadaran tentang ragam bentuk dan tujuan uang serta menangani transaksi moneter sederhana seperti pembayaran harian, pengeluaran, nilai uang, kartu bank, cek, rekening bank, dan mata uang. Konten perencanaan dan pengelolaan finansial mencakup pengetahuan dan kemampuan untuk memantau pemasukan dan pengeluaran serta untuk menggunakan pemasukan dan sumber daya lain yang tersedia dalam jangka pendek dan panjang guna meningkatkan kesejahteraan finansial.

Konten risiko dan imbalan adalah bidang utama literasi finansial, yang menggabungkan kemampuan untuk mengidentifikasi cara mengelola, menyeimbangkan, dan mengatasi risiko serta pemahaman tentang potensi keuntungan atau kerugian finansial di berbagai konteks. Terdapat dua jenis risiko yang sangat penting dalam bidang ini. Yang pertama berkaitan dengan kerugian finansial yang tidak dapat ditanggung seseorang, seperti yang disebabkan oleh bencana atau biaya berulang. Yang kedua adalah risiko yang melekat pada produk finansial, seperti perjanjian kredit dengan suku bunga variabel, atau produk investasi.

Konten lanskap finansial berkaitan dengan karakter dan fitur dunia finansial, yang mencakup pengetahuan hak dan tanggung jawab konsumen di pasar finansial maupun dalam lingkungan finansial umum, serta implikasi utama dari kontrak finansial. Sumber daya informasi dan peraturan hukum juga merupakan topik yang terkait dengan bidang konten lanskap finansial. Dalam arti luas, lanskap finansial menggabungkan pemahaman tentang konsekuensi dari perubahan kondisi ekonomi dan kebijakan publik, seperti perubahan tingkat suku bunga, inflasi, dan perpajakan.

Proses mengidentifikasi informasi finansial digunakan ketika orang mencari dan mengakses sumber informasi finansial, serta mengidentifikasi kaitannya dengan kebutuhan. Informasi ini dapat berbentuk teks cetak seperti kontrak kerja atau digital semisal iklan. Contoh yang mungkin biasa dialami ialah fitur nota dan faktur pembelian serta laporan saldo dalam rekening bank.

Proses menganalisis informasi dalam konteks finansial termasuk menafsirkan, membandingkan, menyintesis, dan mengekstrapolasi informasi yang tersedia. Proses ini melibatkan pengenalan terhadap informasi yang tidak eksplisit, seperti mengidentifikasi asumsi yang mendasari atau implikasi dari masalah tertentu dalam konteks finansial. Contoh paling mudah ialah membandingkan ketentuan yang ditawarkan oleh penyedia layanan jaringan yang berbeda.

Proses mengevaluasi masalah finansial mencakup mengenali atau membangun justifikasi dan penjelasan finansial serta menggunakan pengetahuan dan pemahaman finansial yang diterapkan dalam konteks tertentu. Proses ini melibatkan penjelasan, penilaian, dan generalisasi informasi yang 
tersedia. Karena itu, dalam proses ini diperlukan pemikiran kritis dalam memahami dan membentuk pandangan tentang masalah finansial.

Proses menerapkan pengetahuan dan pemahaman finansial berfokus kepada mengambil tindakan yang efektif dalam pengelolaan finansial berdasarkan pemahaman produk, konteks, dan konsep terkait. Proses ini tercermin dalam kegiatan yang melibatkan perhitungan dan penyelesaian masalah, yang seringkali harus mempertimbangkan kondisi tertentu. Contoh dari proses ini adalah menghitung besaran bunga kredit pembelian barang.

Konteks pendidikan dan pekerjaan termasuk memahami slip pembayaran, merencanakan menabung untuk pendidikan tinggi, menyelidiki manfaat dan risiko ikutserta dalam skema tabungan di lembaga pendidikan atau tempat kerja.

Konteks rumah dan keluarga termasuk masalah finansial yang berkaitan dengan biaya yang diperlukan untuk menjalankan rumah tangga seperti membeli perabotan rumah tangga atau belanjaan keluarga, menyimpan catatan pengeluaran keluarga, serta membuat rencana penganggaran dan prioritas pengeluaran.

Konteks individual mencakup masalah seperti membuka rekening bank, membeli barang konsumsi pribadi, mengeluarkan uang untuk kegiatan pribadi, maupun urusan dengan layanan finansial yang terkait, seperti kredit dan asuransi.

Konteks masyarakat mencakup hal-hal seperti hak dan tanggung jawab konsumen, pajak, dan retribusi daerah, kepentingan bisnis, serta daya beli konsumen. Pilihan finansial seperti menyumbang ke organisasi nirlaba dan lembaha amal juga dapat dimasukkan ke dalam konteks ini.

\section{2) Tahap Design}

Tahap design dimulai dengan menyusun instrumen penilaian pembelajaran sebagai dasar awal menyusun kegiatan pembelajaran (Wiggins \& McTighe, 2005, hal. 13-34). Pilihan ini diambil karena hasil belajar berupa literasi finansial sudah ditentukan, sehingga lebih tepat kalau instrumen penilaian pembelajaran disusun lebih dahulu. Dengan acuan penilaian tersebut, kemudian ditentukan proses pembelajaran yang harus dialami oleh murid. Agar tujuan proses tersebut selaras dengan hasil yang diharapkan, kami turut menyusun LKM. LKM juga berguna untuk memudahkan pelaksanaan sekaligus mengevaluasi proses pembelajaran. Langkah terakhir tahap design ini ialah menyusun program pembelajaran, yang dibuat berdasarkan hasil yang diharapkan dan proses yang memungkinkan untuk dilaksanakan.

Instrumen penilaian pembelajaran yang dipakai dalam penyusunan ini diadaptasi dari instrumen penilaian yang disusun oleh Adib Rifqi Setiawan \& Wahyu Eka Saputri (2020). Instrumen ini dipilih karena ujicoba yang telah dilakukan memberi hasil berupa keseluruhan soal dapat dipakai dengan nilai keandalan sebesar 0,763. Instrumen tersebut disusun dalam tes objektif beralasan untuk menghindari kesubjektifan dalam memeriksa jawaban, mengurangi kesulitan dalam memberikan skor, serta meminimalisir waktu pengoreksian instrumen. Selain itu, dalam urusan finansial, biasanya seseorang sudah memiliki beberapa pilihan dalam membuat keputusan. Keberadaan pilihan jawaban dipakai untuk membiasakan murid untuk membuat keputusan berdasarkan beberapa pilihan. Penambahan alasan dipakai untuk mengurangi peluang menjawab sekaligus membiasakan untuk tidak bertindak secara spekulatif. Sehingga keberadaan alasan dalam penilaian bisa dijadikan faktor 
tebakan (koefisien penilaian). Dengan demikian, penilaian setiap butir soal dilakukan menggunakan persamaan berikut (Setiawan \& Saputri, 2020, hal. 8-9):

$$
\begin{aligned}
& N_{i}=S_{i} \times F_{i} \\
& \text { keterangan: } \\
& N_{i} \quad=\text { nilai setiap butir soal (skor 0-2) } \\
& S_{i} \quad \text { = skor setiap butir pilihan jawaban (nilai 0-1) } \\
& F_{i} \quad \text { = skor faktor tebakan setiap butir soal (nilai 0-2) }
\end{aligned}
$$

(Persamaan 1)

Tabel 2. Klasifikasi Faktor Tebakan

\begin{tabular}{cc}
\hline Skor & Bentuk Uraian \\
\hline 2 & Alasan terkait serta mendukung jawaban yang dipilih \\
\hline 1 & Alasan terkait tanpa mendukung jawaban yang dipilih \\
\hline 0 & Alasan tidak terkait dengan jawaban yang dipilih \\
\hline 0 & Alasan tidak disampaikan \\
\hline
\end{tabular}

Persamaan 1 dan tabel 2 menunjukkan bahwa setiap pilihan jawaban dan alasan dapat memiliki skor sendiri. Skor faktor tebakan dapat maksimal selama alasan terkait serta mendukung jawaban yang dipilih. Namun, karena jawaban yang dipilih salah, nilai yang diperoleh dapat bernilai 0 akibat mengalami operasi perkalian. Begitu pula sebaliknya.

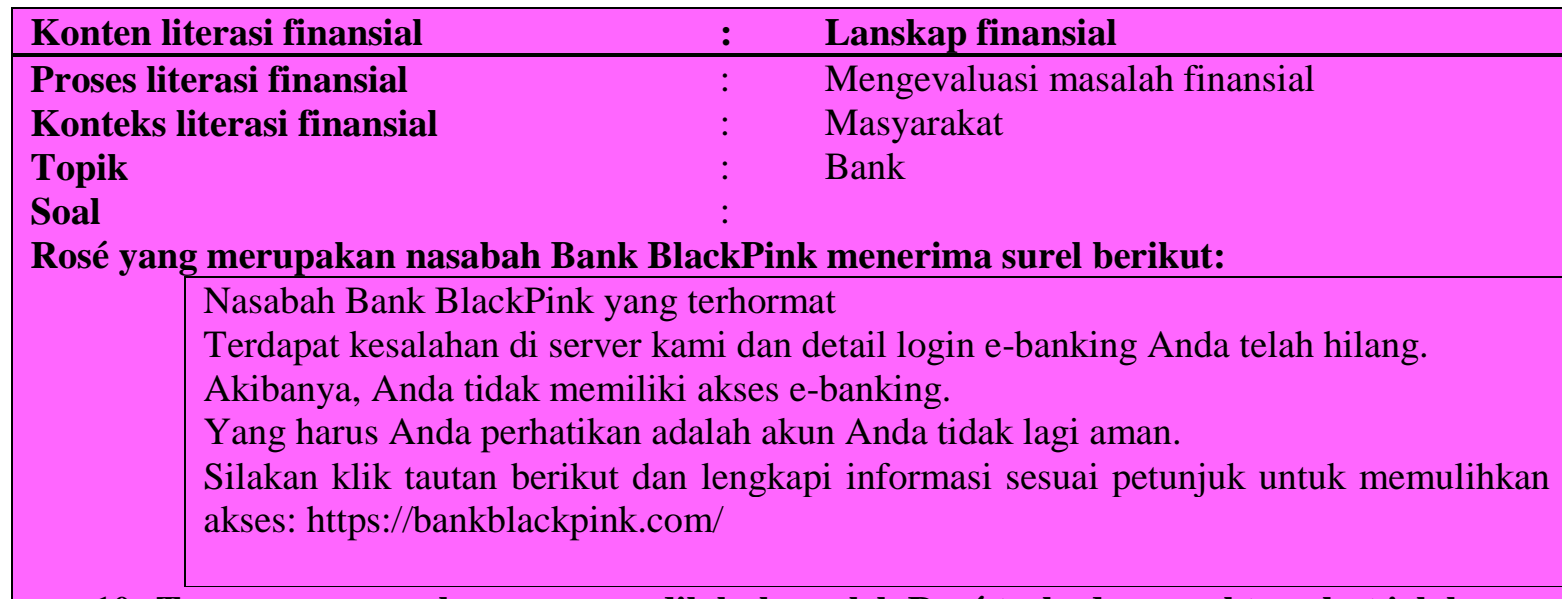

10. Tanggapan yang harus segera dilakukan oleh Rosé terhadap surel tersebut ialah ....

A. Membalas pesan berupa rincian detail login e-banking miliknya.

B. Menghubungi Bank BlackPink untuk menanyakan tentang pesan surel.

C. Mengikuti saran yang dipersilakan oleh pesan surel.

D. Menanyakan pesan tersebut lebih lanjut melalui surel.

Alasan:

\section{Gambar 2. Contoh Butir Soal yang Disusun}

(Setiawan \& Saputri, 2020, hal. 7)

Sampel soal yang disajikan melalui gambar 2 terkait dengan konten lanskap finansial dalam konteks masyarakat. Hal ini karena internet banking adalah bagian dari transaksi finansial yang memiliki banyak fitur dengan ruang lingkup lebih luas daripada urusan pribadi. Proses terkait soal tersebut ialah mengevaluasi masalah finansial karena murid harus mengevaluasi pilihan yang disajikan dan mengenali saran yang lebih menguntungkan atau tidak lebih merugikan untuk diambil. 
Melalui soal tersebut, murid dituntut untuk cakap dalam menganalisis produk finansial sebagai bahan mengambil keputusan ketika menghadapi masalah terkait, seperti penipuan atas nama bank yang disajikan melalui soal. Dari sisi pembelajaran, kegiatan yang menunjang ke arah tersebut ialah pembahasan tentang perbankan, yang dapat diwujudkan dengan beragam model yang biasa diterapkan di tingkat dasar, yakni: ceramah untuk memberi uraian secara utuh terkait dasar perbankan, group work agar dapat melatih murid dalam mengomunikasikan hasil kajian terhadap topik tersebut, serta case-based learning guna membiasakan murid terampil dalam mengambil keputusan ketika menghadapi kasus tertentu (Siayah \& Setiawan, 2020, hal. 7-8).

Dalam pelaksanaan proses pembelajaran, murid diberi LKM yang memuat langkah sesuai dengan indikator yang dibekalkan. Dengan demikian LKM bisa menuntun murid untuk mencapai hasil belajar yang telah ditetapkan. Setiap LKM yang disusun memuat media pembelajaran dalam bentuk video terkait setiap topik, untuk memberi penjelasan singkat dan padat tentang topik yang dibahas. Keseluruhan video tersebut diunggah melalui kanal YouTube dan arsip Internet Archive agar mudah diakses secara daring (Setiawan, 2020; 2020). Pengunggahan ini juga dilakukan agar pembelajaran dapat dilaksanakan ketika guru dan murid tidak dapat hadir bersamaan secara fisik di sekolah seperti ketika masa pandemi virus corona saat ini (Setiawan, 2020, hal. 29-30).

Secara rinci, LKM diberikan untuk meminta murid mengembangkan ulasan yang disampaikan melalui ceramah sebagai bahan menyiapkan keterlibatan dalam group work dan case-based learning. Karena uraian yang disampaikan melalui media cukup singkat, melalui LKM murid juga diarahkan agar mengelaborasi lebih lanjut melalui referensi lain, dalam bentuk verbal, visual, audio, maupun video. Pembiasaan elaborasi juga dimaksudkan agar murid terbiasa belajar secara utuh dan menyeluruh dari beragam jenis referensi.

Tabel 3. Matriks Topik Setiap LKM dengan Konten Literasi Finansial

\begin{tabular}{ccc}
\hline Kode LKM & Topik & Konten Literasi Finansial \\
\hline LF-01 & Kebutuhan dan Keinginan & risiko dan imbalan \\
\hline LF-02 & Konsumen Cerdas & risiko dan imbalan \\
\hline LF-03 & Anggaran & risiko dan imbalan \\
\hline LF-04 & Cita-cita dan Pekerjaan & lanskap finansial \\
\hline LF-05 & Sejarah Uang & uang dan transaksi \\
\hline LF-06 & Mata Uang Tiap Negara & uang dan transaksi \\
\hline LF-07 & Bank & uang dan transaksi \\
\hline LF-08 & ATM (Anjungan Tunai Mandiri) & uang dan transaksi \\
\hline LF-09 & Pajak & risiko dan imbalan \\
\hline LF-10 & Investasi & risiko dan imbalan \\
\hline LF-11 & Asuransi & risiko dan imbalan \\
\hline LF-12 & Meminjam Uang & uang dan transaksi \\
\hline LF-13 & E-money & uang dan transaksi \\
\hline LF-14 & Penggunaan Uang dan Biaya Peluang & lanskap finansial \\
\hline
\end{tabular}

\section{3) Tahap Develop}

Rancangan instrumen penilaian pembelajaran dan LKM tersebut kemudian dianalisis keabsahan dan keandalannya di tahap develop sebagai bahan menyusun program pembelajaran. Keabsahan instrumen penilaian pembelajaran dan LKM ditentukan berdasarkan validasi pakar. Validasi dilakukan terhadap keselarasan instrumen penilaian pembelajaran dan LKM dengan program yang dikembangkan, kesesuaian indikator dengan instrumen penilaian pembelajaran dan LKM, ketepatan 
jawaban dengan pertanyaan dalam instrumen penilaian pembelajaran dan LKM, serta kecocokan tingkat pendidikan dengan instrumen penilaian pembelajaran dan LKM. Kriteria untuk pakar tersebut berupa akademisi dengan bidang kepakaran finansial (Pakar-1), pembelajaran (Pakar-2), dan pendidikan dasar (Pakar-3) serta praktisi profesional bidang finansial (Pakar-4) dan terkait bahasa (Pakar-5).

Tabel 4. Daftar Pakar

\begin{tabular}{cccc}
\hline Pakar & Nama & Institusi & Kepakaran \\
\hline 1 & Muflih Muhammad Mahiry & Universitas Islam Indonesia (UII) & Finansial \\
\hline 2 & Irsad Roxiyul Azmi & Madrasah Tasywiquth Thullab Salafiyyah (TBS) & Pembelajaran \\
\hline 3 & Arij Zulfi Mufassaroh & Pondok Pesantren Annajah YAMRA Merauke & Pendidikan Dasar \\
\hline 4 & Ahmad Ulul Albab & Yayasan Ar-Risalah & Finansial \\
\hline 5 & Matahari & Pondok Pesantren Sumatera Thawalib Parabek & Bahasa \\
\hline
\end{tabular}

Instrumen yang dipakai untuk mengukur keabsahan ialah lembar validasi butir pernyataan. Lembar tersebut diberi skor menggunakan skala Likert (Likert, 1932). Kelebihan skala Likert sebagai pengukur tanggapan secara verbal maupun numerik terhadap kuesioner, dapat memberi nilai kuantitatif dalam rentang spektrum yang panjang. Sedangkan kekurangannya berupa sikap terdistribusi secara normal ke dalam lima kategori persetujuan. Memperhatikan kelebihan dan kekurangan, skala Likert dipilih karena hasilnya dapat diolah baik secara statistik maupun desktriptif. Letak kekurangan berupa pembagian tingkat persetujuan ke dalam lima kategori diatasi dengan menggunakan tujuh tingkat secara numerik.

Nilai keabsahan (validity) ditentukan berdasarkan penilaian pakar terhadap ketepatan antara rancangan dan indikator, pertanyaan dan jawaban, serta soal dengan subjek sasaran (Fraenkel \& Wallen, 2009, hal. 148). Hasil validasi berupa penilaian numerik skala 7 terhadap setiap butir pernyataan yang diolah menggunakan persamaan 2, kemudian ditafsirkan berdasarkan tabel 5, yakni dapat digunakan kalau memenuhi kriteria 'sangat layak' atau 'cukup layak' (Setiawan \& Mufassaroh, 2019, hal. 35).

$$
\begin{aligned}
P(s)= & \frac{s}{N} \times 100 \% \\
& \text { keterangan: } \\
P(s) & =\text { Nilai setiap butir pertanyaan } \\
S & =\text { skor setiap butir pernyataan } \\
N & =\text { jumlah butir pernyataan }
\end{aligned}
$$

(Persamaan 2)

Tabel 5. Penafsiran Penilaian Keabsahan Instrumen

\begin{tabular}{ccc}
\hline No. & Rentang Rerata Penilaian Numerik Pakar (\%) & Kriteria Kelayakan \\
\hline 1 & $7,001 \leq \% \leq 10,000$ & Sangat layak \\
\hline 2 & $4,001 \leq \% \leq 7,000$ & Cukup layak \\
\hline 3 & $0,000 \leq \% \leq 4,000$ & Tidak layak \\
\hline
\end{tabular}

(Setiawan \& Mufassaroh, 2019, hal. 35)

Sementara untuk mengukur keandalan (reliability), dipakai rancangan yang telah diperbaiki berdasarkan lembar validasi. Keandalan instrumen penilaian pembelajaran dan lembar kerja murid ditentukan berdasarkan konsistensi internal (internal consistency). Konsistensi internal biasanya diukur dengan alfa Cronbach $(\alpha)$, salah satu cara statistik untuk mengetahui korelasi berpasangan antar butir pertanyaan atau pernyataan, yang dapat dihitung menggunakan persamaan KuderRichardson Approaches (KR20) berikut (Setiawan, 2019, hal. 6; Cronbach, 1951, hal. 299): 


$$
\begin{gathered}
\alpha=\frac{n}{n-1}\left(1-\frac{\sum_{i} V_{i}}{V_{t}}\right) \\
\text { keterangan: } \\
\alpha \quad=\text { koefisien alfa } \\
n \quad=\text { jumlah butir pernyataan } \\
V i \quad=\text { simpangan baku setiap butir } \\
V t \quad=\text { simpangan baku semua }
\end{gathered}
$$

(Persamaan 3)

Persamaan 3 mengungkap bahwa alfa Cronbach adalah fungsi dari jumlah butir pernyataan serta simpangan baku setiap butir dan keseluruhan. Ini menunjukkkan bahwa nilai alfa Cronbach dapat meningkat ketika interelasi antar butir meningkat. Karena itu, dapat dipakai untuk memperkirakan konsistensi internal sebagai nilai numerik keandalan skor instrumen penilaian pembelajaran dan lembar kerja murid. Persamaan 3 juga bermakna bahwa dibutuhkan uji coba. Hasil ujicoba dapat ditafsirkan berdasarkan tabel 6, yakni dapat dipakai kalau nilai koefisien alfa lebih besar dari 0,70. Dalam melaksanakan ujicoba tersebut kami memilih partisipan sebanyak 102 murid yang dalam pembeljaran dikelompokkan menjadi 3 rombongan belajar (rombel). Keseluruhan partisipan ujicoba

\begin{tabular}{|c|c|c|c|c|c|c|c|}
\hline \multirow{2}{*}{ Kode LKM } & \multicolumn{5}{|c|}{ Skor Setiap Pakar } & \multirow{2}{*}{ Skor Keseluruhan } & \multirow{2}{*}{ Kriteria Kelayakan } \\
\hline & 1 & 2 & 3 & 4 & 5 & & \\
\hline LF-01 & 7 & 6 & 5 & 3 & 3 & 69 & Cukup Layak \\
\hline LF-02 & 5 & 6 & 6 & 7 & 4 & 80 & Sangat Layak \\
\hline LF-03 & 5 & 7 & 6 & 3 & 3 & 69 & Cukup Layak \\
\hline LF-04 & 5 & 6 & 6 & 5 & 3 & 71 & Sangat Layak \\
\hline LF-05 & 5 & 6 & 6 & 5 & 4 & 72 & Sangat Layak \\
\hline LF-06 & 4 & 6 & 7 & 5 & 5 & 77 & Sangat Layak \\
\hline LF-07 & 5 & 5 & 7 & 7 & 4 & 80 & Sangat Layak \\
\hline LF-08 & 6 & 6 & 4 & 4 & 5 & 71 & Sangat Layak \\
\hline LF-09 & 6 & 6 & 4 & 3 & 7 & 74 & Sangat Layak \\
\hline LF-10 & 6 & 5 & 6 & 3 & 4 & 69 & Cukup Layak \\
\hline LF-11 & 6 & 5 & 6 & 3 & 3 & 66 & Cukup Layak \\
\hline LF-12 & 6 & 5 & 6 & 5 & 4 & 72 & Cukup Layak \\
\hline LF-13 & 6 & 6 & 6 & 3 & 5 & 74 & Sangat Layak \\
\hline LF-14 & 5 & 3 & 7 & 2 & 3 & 57 & Cukup Layak \\
\hline
\end{tabular}
dipilih menggunakan teknik convenience sampling untuk menghemat tenaga karena kami terlibat sebagai pemandu pembelajaran aktual partisipan.

Tabel 6. Penafsiran Penilaian Keandalan Instrumen

\begin{tabular}{ccc}
\hline No. & Nilai Alfa Cronbach & Kategori Keandalan \\
\hline 1 & $\alpha \leq 0,9$ & Luar biasa \\
\hline 2 & $0,8 \leq \alpha<0,9$ & Baik \\
\hline 3 & $0,7 \leq \alpha<0,8$ & Dapat diterima \\
\hline 4 & $0,6 \leq \alpha<0,7$ & Dipertanyakan \\
\hline 5 & $0,5 \leq \alpha<0,6$ & Rendah \\
\hline 6 & $\alpha<0,5$ & Tidak dapat diterima \\
\hline
\end{tabular}

Tabel 7. Hasil Validasi Pakar terhadap Instrumen Penilaian Pembelajaran 
Hasil dari tahap develop berupa validasi pakar dan ujicoba digunakan sebagai bahan penyusunan program pembelajaran dalam bentuk silabus. Berdasarkan pertimbangan prioritas pembahasan, tingkat penalaran, serta struktur kurikulum, sasaran program pembelajaran ialah murid yang sudah mengalami pembelajaran nilai mata uang. Dalam bentuk aktual, sasaran tersebut tampak secara langsung mengarah kepada murid mulai kelas 2 MI/SD. Namun, tidak menutup kemungkinan murid di luar himpunan tersebut masuk ke dalam sasaran program pembelajaran. Yang jelas, program pembelajaran dapat disebar mulai kelas 2-6 maupun dijadikan satu kesinambungan dalam satu tahun untuk kelas 5 atau 6.

Kaitan antara silabus dengan instrumen penilaian pembelajaran dan LKM mewujud dalam bentuk rencana pelaksanaan pembelajaran (RPP, lesson plan). Selanjutnya instrumen penilaian pembelajaran, LKM, dan RPP dapat disebarkan secara luas dalam satu paket perangkat pembelajaran atau terpisah. Satu paket yang dimaksud ialah digunakan seutuhnya berdasarkan kerja kami. Sedangkan terpisah berarti hanya diambil seperlunya, seperti instrumen penilaian pembelajaran untuk mengukur profil literasi finansial pelajar. Keterbatasan tenaga membuat kami tidak melakukan penyebaran secara luas yang merupakan tahap terakhir berupa disseminate.

\section{D) Penutup}

Riset ini memberi hasil berupa desain pembelajaran untuk membimbing murid tingkat dasar dalam memperoleh literasi finansial, yang keabsahan dan keandalan secara umum termasuk dalam kategori dapat digunakan. Simpulan yang kami sampaikan menunjukkan bahwa pembelajaran di tingkat dasar dapat menjadi sarana untuk memandu murid untuk memiliki literasi finansial.

Dalam riset sosial, hasil yang diperoleh tidak memberi garansi bahwa keabsahan dan keandalan yang sama dapat berlaku untuk partisipan lain (Setiawan, 2020, hal. 65). Alasannya antara lain, ruang lingkup pembahasan berada dalam spektrum tertentu. Kalau hanya mengambil simpulan akhir tanpa memperhatikan rincian tertentu seperti metode dan fokus pembahasan, berarti yang terjadi adalah implantasi atau pencangkokan.

Dengan demikian, kami menganggap bahwa kerja yang kami lakukan ini masih perlu dilanjutkan. Sehingga diharapkan penyusunan program ini tidak dianggap final, bahkan perlu dilakukan pengembangan berlanjut hingga membuahkan hasil optimal. 


\section{Referensi}

al-Maḥallī, M. i., \& al-Suyūṭị, ‘. a.-R. (2010). Tafsīr al-Jalālayn. Cairo: Dār al-Hadīts.

Cronbach, L. J. (1951, September). Coefficient Alpha and the Internal Structure of Tests. Psychometrika, 16, 297-334.

Fraenkel, J. R., \& Wallen, N. E. (2009). How to Design and Evaluate Research in Education (7 ed.). New York City: McGraw-Hill Companies.

Kementerian Sekretariat Negara RI. (2013, November 19). Sambutan Presiden RI Pd Strategi Nasional Literasi Keuangan, tgl Nov 19. 2013 , di JCC Selasa, 19 November 2013. Dipetik Februari 4, 2021, dari Kementerian Sekretariat Negara RI:

https://www.setneg.go.id/baca/index/sambutan_presiden_ri_pd_strategi_nasional_literasi_fin ansial_tgl_19_nov_2013_di_jcc

Likert, R. (1932). A Technique for the Measurement of Attitudes. Archives of Psychology, 140, 155.

OECD. (2005). Recommendation on Principles and Good Practices for Financial Education and Awareness. Paris: Directorate for Financial and Enterprise Affairs.

OECD. (2015). National Strategies for Financial Education: OECD/INFE Policy Handbook. Paris: OECD Publishing.

OECD. (2019). PISA 2018 Assessment and Analytical Framework. Paris: OECD Publishing.

OJK. (2017). Strategi Nasional Literasi Finansial Indonesia (revisit 2017). Jakarta Pusat: Otoritas Jasa Finansial (OJK).

Setiawan, A. R. (2019). Penyusunan Program Pembelajaran Biologi Berorientasi Literasi Saintifik. Seminar Nasional Sains \& Entrepreneurship VI (hal. 255). Semarang: Universitas PGRI Semarang (UPGRIS).

Setiawan, A. R. (2020, April 21). Lembar Kegiatan Literasi Saintifik untuk Pembelajaran Jarak Jauh Topik Penyakit Coronavirus 2019 (COVID-19). Edukatif, 2(1), 28-37.

Setiawan, A. R. (2020, September 4). Literasi Finansial. Dipetik Februari 4, 2021, dari YouTube $\Lambda$ LОВ $\Lambda$ ТИІР:

https://youtube.com/playlist?list=PL8jJiYrUiGXBKN4h80bPQ1CmvAMRTGqtn

Setiawan, A. R. (2020, Oktober 19). Literasi Finansial Tingkat Dasar. Dipetik Februari 4, 2021, dari Internet Archive: https://archive.org/details/literasi-finansial-tingkat-dasar

Setiawan, A. R. (2020, Januari 24). Pembelajaran Tematik Berorientasi Literasi Saintifik. Jurnal BasicEdu, 4(1), 51-69.

Setiawan, A. R., \& Mufassaroh, A. Z. (2019, Juni 28). Menyusun Soal Literasi Saintifik untuk Pembelajaran Biologi. BIOSFER: Jurnal Biologi dan Pendidikan Biologi, 4(1), 33-40.

Setiawan, A. R., \& Saputri, W. E. (2020, May 26). Assessment Instrument of Financial Literacy for Fiqh Mu'āmalāt Learning Based on Kitab Kuning. Thesis Commons, 1-10.

Siayah, S., \& Setiawan, A. R. (2020, April 13). A Brief Explanation of Science Education. Thesis Commons, 1-12.

Thiagarajan, S., Semmel, D. S., \& Semmel, M. I. (1974). Instructional Development for Training Teachers of Exceptional Children: A Sourcebook. Washington, D. C.: National Center for Improvement of Educational Systems (DHEW/OE).

Ummah, N. (2018, Desember 18). Mana yang Lebih Penting??? Nilai Angka atau Lifeskill??

(Kurikulum Bintang Mulia Homeschooling). Dipetik Februari 4, 2021, dari YouTube Bintang Mulia Homeschooling: https://youtu.be/ag0N5EkTY-U

Wiggins, G. P., \& McTighe, J. (2005). Understanding by Design (2 ed.). Alexandria: ACDC (Association for Supervision and Curriculum Development). 